\title{
A. Ronsin, B. Houot, A. Litaize A., P. Joudrier, N. Lefranc, S. Lajugée, J.-F. Duval, 2004, Vosges, encyclopédie Bonneton.
}

Paris, Ch. Bonneton, 320 p.

Jean-Pierre Husson

\section{OpenEdition}

Journals

Édition électronique

URL : http://journals.openedition.org/rge/2415

DOI : $10.4000 /$ rge.2415

ISSN : $2108-6478$

Éditeur

Association des géographes de l'Est

Édition imprimée

Date de publication : 1 juin 2003

ISSN : 0035-3213

\section{Référence électronique}

Jean-Pierre Husson, «A. Ronsin, B. Houot, A. Litaize A., P. Joudrier, N. Lefranc, S. Lajugée, J.-F. Duval, 2004, Vosges, encyclopédie Bonneton. ", Revue Géographique de l'Est [En ligne], vol 43 / 3 | 2003, mis en ligne le 01 décembre 2010, consulté le 25 septembre 2020. URL : http://journals.openedition.org/rge/ 2415 ; DOI : https://doi.org/10.4000/rge.2415

Ce document a été généré automatiquement le 25 septembre 2020.

Tous droits réservés 


\section{A. Ronsin, B. Houot, A. Litaize A., P. Joudrier, N. Lefranc, S. Lajugée, J.-F. Duval, 2004, Vosges, encyclopédie Bonneton.}

Paris, Ch. Bonneton, $320 \mathrm{p}$.

Jean-Pierre Husson

\section{RÉFÉRENCE}

A. Ronsin, B. Houot, A. Litaize A., P. Joudrier, N. Lefranc, S. Lajugée, J.-F. DUVAL, 2004, Vosges, encyclopédie Bonneton. Paris, Ch. Bonneton, $320 \mathrm{p}$.

1 Cette collection régionale superbement illustrée s'enrichit d'un nouveau tome consacré au département des Vosges. Selon la formule éprouvée, ce beau livre qui intéresse un public élargi et éclairé, s'organise en cinq chapitres : histoire et art, ethnographie (avec une présentation des types d'habitats traditionnels appuyée sur les recherches effectuées par G. Savouret), langue et littérature, milieux naturels et économie. De très belles pages sont laissées à la présentation des écosystèmes et des espèces qui sont inféodées aux différents milieux riches d'une biodiversité préservée, parfois renouvelée après le passage de Lothar. Le dernier chapitre dépeint un département encore assez fortement industrialisé, de plus en plus structuré autour de l'axe formé par la Moselle. Ce département abrite entre autre quelques grands noms de l'industrie agroalimentaire (Vittel, Contrexéville, Ermitage, Thiriet) et joue pleinement la carte des formes de tourisme vert et d'accueil. 


\section{AUTEUR}

JEAN-PIERRE HUSSON

Université Nancy 2 